\title{
Arginine Uptake by a Psychrophilic Marine Vibrio sp. During Starvation-induced Morphogenesis
}

\author{
By WILLIAM C. FAQUIN† AND JAMES D. OLIVER* \\ Department of Biology, University of North Carolina at Charlotte, Charlotte, NC 28223, USA
}

(Received 4 August 1983; revised 5 December 1983)

\begin{abstract}
The effects of starvation on the arginine transport system in ANT-300, a psychrophilic marine Vibrio sp., were investigated. A rapid rate of uptake was detected on the first day of starvation, followed by a much lower but constant rate of uptake until day 35 . Transport was found to require maintenance of a proton gradient across the membrane, but not to involve ATP. Respiration of the transported arginine increased during the $35 \mathrm{~d}$ of starvation. Thus, ANT-300 is able to maintain a high-affinity, active transport system for arginine during extended periods of starvation even in the absence of an exogenously supplied energy source.
\end{abstract}

\section{INTRODUCTION}

The open ocean is characterized by low temperature $\left(5^{\circ} \mathrm{C}\right)$, low nutrient concentration (less than $1 \mathrm{mg}$ dissolved organic carbon per litre in surface waters and less than $0.5 \mathrm{mg}$ dissolved organic carbon per litre in deep waters), and elevated hydrostatic pressure (an average of $500 \mathrm{~atm}$ ). In order for a metabolically active bacterial population to exist in the open ocean, it must be able to remain viable under these conditions. A psychrophilic Vibrio sp. (ANT-300) isolated from the Antarctic Ocean was found to decrease in size and change in shape from a rod to a coccus during nutrient starvation (Novitsky \& Morita, 1976). Further, as much as a 200 -fold increase in cell number was observed during this morphogenesis (Novitsky \& Morita, 1977, 1978), with a significant portion of the population remaining viable for more than one year (Novitsky \& Morita, 1977). When compared with other bacteria, ANT-300 exceeds the longest reported starvation survival by at least 2.5 times (Novitsky \& Morita, 1978). Amy \& Morita (1983) have shown such a starvation response not to be unique to ANT-300, but to be typical of marine bacteria.

ANT-300 was also found to exhibit barotolerance, but only if starved for one week prior to pressurization. While pressure has been observed to inhibit amino acid transport in marine bacteria (Paul \& Morita, 1971), Geesey \& Morita (1979) identified a transport mechanism for arginine in ANT-300 which functioned in the absence of an exogenously supplied energy source. This transport mechanism was found to be bimodal, with low-affinity substrate transport, coupled with a chemotactic response, being expressed at arginine concentrations above $0.25 \mu \mathrm{M}$, and high-affinity transport at concentrations less than $0.25 \mu \mathrm{M}$. Geesey \& Morita (1979) proposed, therefore, that ANT-300 might be able to capture arginine in the open ocean, where amino acid concentrations are below $0.05 \mu \mathrm{M}$ (Menzel \& Ryther, 1970), by using high-affinity active transport. Even though amino acid transport is inhibited by elevated hydrostatic pressure, possession of such a high-affinity transport system, coupled with reduced endogenous metabolism, would enhance survival in the ocean. The present investigation was therefore undertaken to examine the effects of long-term starvation on the high-affinity arginine transport system in ANT-300. While ANT-300 cells which are nutrient-starved for 18-24 h are known to possess such a system, its long-term operation as the cells progress from unstarved, rod-shaped cells to starvation-induced, coccal cells, has not been previously reported.

† Present address: Department of Biology, Harvard University, Cambridge, Mass., USA.

Abbreviations: ASW, artificial seawater; DNP, 2,4-dinitrophenol. 


\section{METHODS}

Organism and growth conditions. Vibrio sp. ANT-300 was obtained from Dr R. Y. Morita (Oregon State University, USA). It was cultured in the marine medium MSWYE (Oliver \& Colwell, 1973) with shaking at $5{ }^{\circ} \mathrm{C}$. Cells from $100 \mathrm{ml}$ of the medium were harvested during the exponential phase of growth at $10000 \mathrm{~g}$ for $10 \mathrm{~min}$, washed twice in cold artificial seawater (ASW: $\mathrm{NaCl}, 24.72 \mathrm{~g} ; \mathrm{KCl}, 0.67 \mathrm{~g} ; \mathrm{CaCl}_{2} .2 \mathrm{H}_{2} \mathrm{O}, 1.36 \mathrm{~g} ; \mathrm{MgCl}_{2} .6 \mathrm{H}_{2} \mathrm{O}$, $4.66 \mathrm{~g} ; \mathrm{MgSO}_{4} .7 \mathrm{H}_{2} \mathrm{O}, 6.29 \mathrm{~g} ; \mathrm{NaHCO}_{3}, 0.18 \mathrm{~g}$, and 1 litre $\mathrm{H}_{2} \mathrm{O}$ ), and resuspended in $5 \mathrm{ml}$ cold, sterile ASW. To each of six $125 \mathrm{ml}$ flasks containing $50 \mathrm{ml}$ sterile ASW (chilled to $5^{\circ} \mathrm{C}$ ), $0.2 \mathrm{ml}$ of the ANT-300 suspension was added. The resulting cell suspensions were gently shaken at $5^{\circ} \mathrm{C}$.

Uptake and respiration studies. At $0,1,2,5,10$ and $35 \mathrm{~d}, 5 \mathrm{ml}$ samples of the starved population were placed into each of nine airtight reaction flasks containing $75 \mu \mathrm{L}-\left[\mathrm{U}-{ }^{14} \mathrm{C}\right]$ arginine at $100 \mu \mathrm{Ci} \mu \mathrm{mol}^{-1}\left(3700 \mathrm{kBq} \mu \mathrm{mol}^{-1}\right)$ (ICN, Irvine, Calif., USA). The final arginine concentration in each flask was $0.05 \mu \mathrm{M}$. Three of the reaction flasks contained $1 \mathrm{mg} \mathrm{HgCl} 2$ as controls. Then, at 1,5 and $15 \mathrm{~min}$, one control flask and two experimental flasks were acidified by injection of $0.2 \mathrm{ml} 3 \mathrm{M}-\mathrm{H}_{2} \mathrm{SO}_{4}$. Following gentle shaking for $30 \mathrm{~min}, 0.3 \mathrm{ml} \beta$-phenethylamine was injected into a basket suspended in each flask and containing Whatman filter paper. The flasks were shaken for an additional $30 \mathrm{~min}$, and the contents of each were then poured through a $0.22 \mu \mathrm{m}$ membrane filter (Millipore). The flasks were rinsed three times with $5 \mathrm{ml}$ cold ASW, and the rinses used to wash the filters, which were then allowed to dry overnight at room temperature. The Whatman filter papers (containing the respired ${ }^{14} \mathrm{CO}_{2}$ ) and the Millipore filters (containing the cells and $\left[{ }^{14} \mathrm{C}\right]$ arginine taken up) were assayed for radioactivity by using a toluene-based scintillation fluid, comprising toluene, 11 ; bis-MSG [ $p$-bis $(o$-methylstyryl)benzene], $80 \mathrm{mg}$; PPO, $3.9 \mathrm{~g}$, and counting in a Beckman model 250 scintillation counter.

Effect of metabolic inhibitors. Cells of ANT-300, prepared as described above, were removed at various intervals and treated with chloramphenicol $\left(80 \mu \mathrm{g} \mathrm{ml}^{-1}\right)$ and either 2,4-dinitrophenol (DNP) at $2 \mathrm{mM}$ or sodium arsenate at $200 \mathrm{mM}$, as described by Geesey \& Morita (1979). Control cells received no inhibitors. Uptake of $\left[{ }^{14} \mathrm{C}\right]$ arginine was monitored, in duplicate, as described above.

Cell population assays. At each sampling time $(0,1,2,5,10,35 \mathrm{~d})$, direct cell counts of the starved ANT-300 population were made using a Petroff-Hauser counting chamber. Total viable counts were also determined by plating onto cold MSWYE agar.

\section{RESULTS}

There was no increase in numbers of ANT-300 as indicated by direct counts, compared to the initial population $\left(1.2 \times 10^{7}\right.$ cells $\left.\mathrm{ml}^{-1}\right)$, until day 2 of starvation (Fig. 1). At that time the cell population increased and reached a maximum of $2.0 \times 10^{7}$ cells $\mathrm{ml}^{-1}$ by day 5 , followed by a gradual decrease to $7 \times 10^{6}$ cells $\mathrm{ml}^{-1}$ by day 35 . Total viable counts (Fig. 1) showed a trend similar to that observed for direct counts, although the absolute numbers were lower. Phasecontrast microscopy revealed the appearance of small rods $(1-2 \mu \mathrm{m}$ long) during days $1-3$ of starvation and subsequent formation of spherical cells $(0.5 \mu \mathrm{m}$ diameter $)$ between days 10 and 35 .

Fig. 2 shows the uptake of $\left[{ }^{14} \mathrm{C}\right]$ arginine by ANT -300 cells when exposed to the amino acid for periods of 1 to $15 \mathrm{~min}$. Uptake for the $1 \mathrm{~min}$ sample decreased from an initial 2.7 pmol per $10^{7}$ cells to a fairly constant $0.7-0.9 \mathrm{pmol}$ per $10^{7}$ cells between days 2 and 35 of starvation. The uptake curves for arginine at 5 and $15 \mathrm{~min}$ were similar to that seen in the $1 \mathrm{~min}$ sample. Whereas cells starved for only $24 \mathrm{~h}$ were able to transport arginine at an appreciable rate for up to at least $15 \mathrm{~min}$ (Table 1), after $48 \mathrm{~h}$ starvation the rate decreased to only $0.7-0.9 \mathrm{pmol} \mathrm{min}^{-1}$ per $10^{7}$ cells during even the first minute of transport. Uptake rates remained constant at this level after $48 \mathrm{~h}$ starvation.

Respiration of the transported arginine was expressed as the percentage of total labelled arginine taken up and respired to ${ }^{14} \mathrm{CO}_{2}$. Although slight differences were observed for respiration following transport of label for 1,5 and $15 \mathrm{~min}$, the overall pattern of respiration was not appreciably different for any of the three incorporation periods (Fig. 3). The initial range for respiration of arginine was $7 \cdot 2-19.5 \%$ of the total arginine transported. Respiration tended to increase with increased starvation time, with the final range on day 35 of starvation being between 35.9 and $59.4 \%$. In a preliminary starvation study conducted over a $116 \mathrm{~d}$ period (data not shown), the respiration of arginine similarly increased during the initial days of starvation but the percentage respired began to decrease after day 42 , and reached a minimum at day 116 . At 


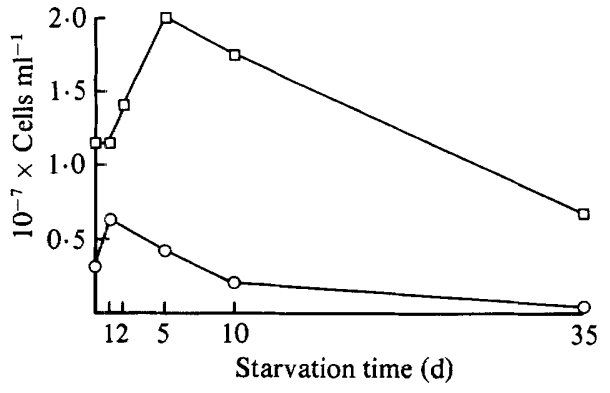

Fig. 1. Changes in cell counts of ANT-300 during starvation. $\square$, Direct cell counts; $\bigcirc$, total viable counts.

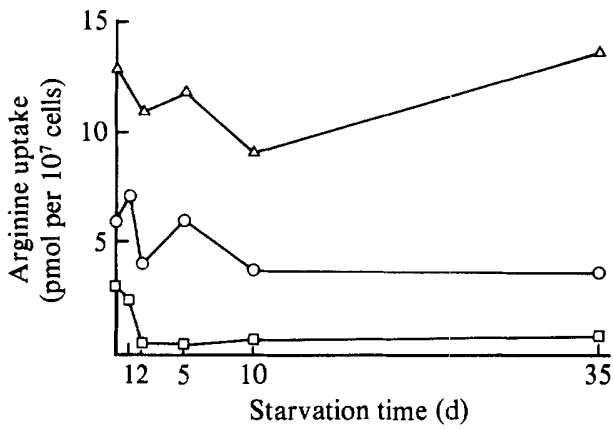

Fig. 2

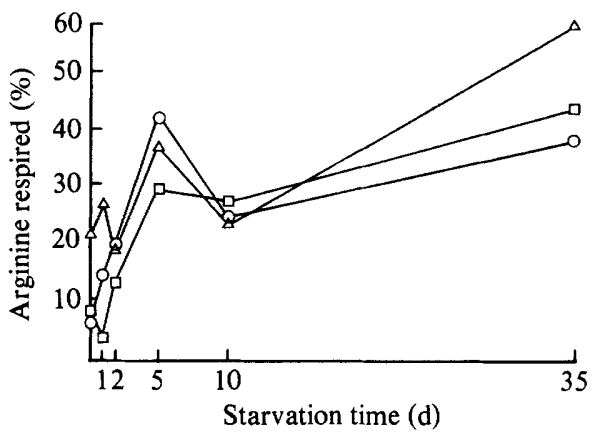

Fig. 3

Fig. 2. Total uptake of arginine in ANT-300 during $35 \mathrm{~d}$ of starvation after exposure to arginine. Exposure times: $\square, 1 \mathrm{~min} ; O, 5 \mathrm{~min} ; \triangle, 15 \mathrm{~min}$. The SEM did not exceed $\pm 9 \%$ for any samples. Values based on direct counts.

Fig. 3. Percentage of arginine respired in ANT-300 during $35 \mathrm{~d}$ of starvation after exposure to arginine. Exposure times: $\square, 1 \mathrm{~min}$; $O, 5 \mathrm{~min} ; \triangle, 15 \mathrm{~min}$. The SEM did not exceed $\pm 8 \%$.

Table 1. Rate of arginine uptake in Vibrio sp. ANT-300

\begin{tabular}{|c|c|c|c|c|}
\hline \multirow{2}{*}{$\begin{array}{l}\text { Starvation } \\
\text { time (d) }\end{array}$} & \multirow{2}{*}{$\begin{array}{l}\text { Exposure to } \\
\text { arginine } \ldots\end{array}$} & \multicolumn{3}{|c|}{$\begin{array}{c}\text { Total arginine uptake* } \\
\left(\mathrm{pmol} \min ^{-1} \text { per } 10^{7} \text { cells } \dagger\right)\end{array}$} \\
\hline & & $1 \mathrm{~min}$ & $5 \mathrm{~min}$ & $15 \mathrm{~min}$ \\
\hline 0 & & $2 \cdot 7$ & $1 \cdot 2$ & 0.8 \\
\hline 1 & & $2 \cdot 3$ & $1 \cdot 3$ & $1 \cdot 3$ \\
\hline 2 & & 0.7 & 0.8 & 0.7 \\
\hline 5 & & 0.7 & $1 \cdot 1$ & 0.8 \\
\hline 10 & & 0.8 & 0.8 & 0.6 \\
\hline 35 & & 0.9 & 0.6 & 0.9 \\
\hline
\end{tabular}

* The SEM did not exceed $\pm 9 \%$ at any period.

$\dagger$ Cell numbers determined by direct counts.

that point, the 1 min sample showed no respiration of arginine, while the 5 and 15 min samples showed respired levels of only $2 \cdot 1 \%$ and $10 \cdot 2 \%$, respectively, of the total label taken up.

A separate study was conducted to examine the effects of two metabolic inhibitors on the uptake of arginine, to determine whether transport was via an active process. Little difference was observed in the amount of arginine transported by control cells and those treated with arsenate, which disrupts ATP metabolism (Table 2). The uncoupler DNP, however, decreased arginine transport by the cells by $42-64 \%$ relative to the control values, indicating that the maintenance of a proton gradient is an important aspect of the uptake mechanism. 
Table 2. Effects of metabolic inhibitors on uptake of arginine

\begin{tabular}{ccccc} 
Starvation & \multicolumn{3}{c}{ Arginine uptake* } \\
\cline { 2 - 5 } time (d) & Inhibitor . . None & Arsenate & DNP \\
0 & & 543 & $541(0 \cdot 4)$ & $195(64 \cdot 1)$ \\
2 & & 351 & $323(8 \cdot 0)$ & $204(41 \cdot 9)$ \\
8 & 155 & $197(0)$ & $73(52 \cdot 9)$ \\
23 & 251 & $175(30 \cdot 2)$ & $102(59 \cdot 4)$ \\
Mean \% inhibition & - & $9 \cdot 7$ & $54 \cdot 6$
\end{tabular}

${ }^{*}$ Uptake of $\left[\mathrm{U}^{14} \mathrm{C}\right]$ arginine is shown as d.p.m. $\min ^{-1}$ per ml culture; the percentage decrease as compared with the control is shown in parentheses.

\section{DISCUSSION}

Both the direct cell counts and total viable counts observed in this study (Fig. 1), match the morphogenetic pattern reported in several studies by Morita and co-workers (Amy \& Morita, 1983; Amy et al., 1983; Novitsky \& Morita, 1977) for ANT-300 during starvation. ANT-300 increased in cell number by $64-67 \%$ through division of the rod form to yield small rods $1-2 \mu \mathrm{m}$ long, and by day 35 of starvation small spherical cells $(0.4-0.6 \mu \mathrm{m})$ were the predominant morphological form. A gradual decrease in the number of viable cells in the starving ANT-300 population occurred on increased starvation (Fig. 1). This decrease, which does not result from cell lysis (Kurath \& Morita, 1973), has been shown to eventually level off so that a significant population remains viable for periods exceeding 1.5 years (Novitsky \& Morita, 1978), indicating that ANT-300 is well adapted for survival in low nutrient conditions.

We examined transport of arginine at a concentration of $0.05 \mu \mathrm{M}$, a value approximately equal to that reported for amino acids in open ocean waters (Menzel \& Ryther, 1970), and slightly lower than the concentration $(0.07 \mu \mathrm{M})$ used by Geesey \& Morita (1979). At this arginine concentration the high-affinity transport system operates and it was seen to remain functional during the $35 \mathrm{~d}$ starvation period in the present study (Fig. 2).

The decrease in the initial rate of arginine uptake in ANT-300 is probably related either to the $80 \%$ decrease in endogenous metabolism which occurs during the first $2 \mathrm{~d}$ of starvation (Novitsky \& Morita, 1977), or to a change in the arginine binding proteins of the bacterium. Geesey \& Morita (1981) showed that arginine binding proteins in ANT-300 are located on or near the surface of intact cells. The decreased uptake rate is most probably due to a saturation of the membrane binding proteins or the transport permeases, or of both.

Research on Vibrio harveyi (Makemson \& Hastings, 1979) and Escherichia coli (Celis et al., 1973; Rosen, 1973) indicates that these bacteria possess several distinct transport systems for basic amino acids: two for lysine, two for arginine, one for ornithine, and a high-affinity transport system common to all three. Our results may, thus, reflect a combination of different transport systems. It is also possible that in ANT-300 more than one transport system for arginine is initially active and on starvation one system may become (or remain) functional while the other(s) shuts down.

Transport of arginine in ANT-300 was found to be largely independent of ATP since arsenate, which is known to decrease intracellular ATP content (Tokuda \& Unemoto, 1982), had little effect on the uptake of arginine (Table 2). This is in agreement with the conclusion of Geesey \& Morita (1979) that ATP-driven active transport of arginine is not significant during starvation. We have also observed (Stringer \& Oliver, 1984) that the ATP content of starving ANT-300 cells decreases from $1.5 \times 10^{-15} \mathrm{~g}$ per cell $\left(47 \mathrm{ng} \mathrm{ml}^{-1}\right)$ to $0.39 \times 10^{-15} \mathrm{~g}$ per cell $\left(16 \mathrm{ng} \mathrm{ml}^{-1}\right)$ after $21 \mathrm{~d}$ starvation. That uptake of arginine could continue for $15 \mathrm{~min}$ at the same rate as observed for 1 min in cells of ANT-300 starved for $35 \mathrm{~d}$ (Table 1) further suggests that the cellular ATP content is not a major factor in the ability of ANT-300 to transport arginine. The uncoupler DNP, on the other hand, greatly decreased the amount of arginine transported (Table 2). Thus, as in cells of ANT-300 starved for up to $24 \mathrm{~h}$ (Geesey \& Morita, 1979), arginine transport continues through an active mechanism during long-term starvation. 
Respiration of arginine in ANT-300 increased markedly from day 0 to day 35 . Between these times, however, there was a distinct peak in arginine respiration which occurred in all three transport times at the $5 \mathrm{~d}$ sampling (Fig. 3). This pattern is remarkably similar to that reported by Amy et al. (1983). Thus, both studies indicate the long-term potential of ANT-300 to respire nutrients as they become available. The overall increase in respiration was expected as a result of the stress caused by starvation; to overcome this stress, cells respire more of the transported substrate, thus permitting maintenance of cellular integrity (Morita, 1975).

In a preliminary study performed over $116 \mathrm{~d}$, the initial increase in arginine respired was similar to that demonstrated in the $35 \mathrm{~d}$ starvation study. The extended study indicated, however, that, while arginine uptake remained significant at the $116 \mathrm{~d}$ sampling, respiration of arginine decreased to between 0 and $10.2 \%$ for the three samples. These data suggest that, while arginine is being transported into the cell, it is either being maintained in an amino acid pool or incorporated into protein rather than being respired.

In conclusion, ANT-300 shows characteristics of a successfully adapted bacterial population in the deep sea: it is able to exist at low temperatures and at low nutrient levels. In the present study, a high-affinity transport system for arginine in ANT-300 has been found to be of an active type, and to function during long-term nutrient starvation and in the absence of an exogenously supplied energy source.

This study was supported, in part, by a John Yarbrough grant to W.C.F. from the North Carolina Academy of Science. The secretarial assistance of Mimi Taylor is gratefully acknowledged.

\section{REFERENCES}

AMY, P. S. \& MoRITA, R. Y. (1983). Starvation-survival patterns of sixteen freshly isolated open-ocean bacteria. Applied and Environmental Microbiology 45, 1109-1115.

Amy, P. S., Pauling, C. \& Morita, R. Y. (1983). Starvation-survival processes of a marine vibrio. Applied and Environmental Microbiology 45, 10411048.

Celis, T. F. R., Rosefeld, H. J. \& MAas, W. K. (1973). Mutant of $E$. coli K-12 defective in the transport of basic amino acids. Journal of Bacteriology 116, 619626.

GeESEY, G. G. \& MoRita, R. Y. (1979). Capture of arginine at low concentrations by a marine psychrophilic bacterium. Applied and Environmental Microbiology 38, 1092-1097.

GeEseY, G. G. \& Morita, R. Y. (1981). Relationship of cell envelope stability to substrate capture in a marine psychrophilic bacterium. Applied and Environmental Microbiology 42, 533-540.

KURATH, G. \& MORITA, R. Y. (1983). Starvationsurvival physiological studies of a marine Pseudomonas sp. Applied and Environmental Microbiology 45, 1206-1211.

Makemson, J. C. \& Hastings, J. W. (1979). Poising of the arginine pool and control of bioluminescence in Beneckea harveyi. Journal of Bacteriology 140, 532547.

MenZel, D. W. \& Ryther, J. H. (1970). Distribution and cycling of organic matter in the oceans. In Organic Matter in Natural Waters, pp. 31-54. Fairbanks: Institute of Marine Science of the University of Alaska.
MORITA, R. Y. (1975). Psychrophilic bacteria. Bacteriological Reviews 39, 144-167.

Novitsky, J. A. \& MoRITA, R. Y. (1976). Morphological characterization of small cells resulting from nutrient starvation of a psychrophilic marine Vibrio. Applied and Environmental Microbiology 32, 617622.

Novitsky, J. A. \& MoRITA, R. Y. (1977). Survival of a psychrophilic marine Vibrio under long-term nutrient starvation. Applied and Environmental Microbiology 33, 635-641.

Novitsky, J. A. \& Morita, R. Y. (1978). Possible strategy for the survival of marine bacteria under starvation conditions. Marine Biology 48, 289-295.

Oliver, J. D. \& Colwell, R. R. (1973). Extractable lipids of Gram-negative marine bacteria: phospholipid composition. Journal of Bacteriology 114, 897908.

Paul, K. L. \& Morita, R. Y. (1971). Effects of hydrostatic pressure and temperature on the uptake and respiration of amino acids by a facultatively psychrophilic marine bacterium. Journal of Bacteriology 108, 835-843.

Rosen, B. P. (1973). Basic amino acid transport in $E$. coli. Journal of Bacteriology 116, 627-635.

Stringer, W. F. \& Oliver, J. D. (1984). Lipid composition of a psychrophilic marine Vibrio sp. during starvation-induced morphogenesis. Applied and Environmental Microbiology 47, 461-466.

TOKUDA, H. \& UNEMOTO, T. (1982). Characterization of the respiration-dependent $\mathrm{Na}^{+}$pump in the marine bacterium Vibrio alginolyticus. Journal of Biological Chemistry 257, 10007-10014. 